\title{
EIGHTY YEARS OF ELECTROCONVULSIVE THERAPY IN CROATIA AND IN SESTRE MILOSRDNICE UNIVERSITY HOSPITAL CENTRE
}

\author{
Dalibor Karlović ${ }^{1,2,3}$, Vivian Andrea Badžim ${ }^{1}$, Marinko Vučić ${ }^{4}$, Helena Krolo Videka ${ }^{4}$, \\ Ana Horvat ${ }^{4}$, Vjekoslav Peitl ${ }^{1,3}$, Ante Silić, ${ }^{1,3}$, Branka Vidrih ${ }^{1,3}$, Branka Aukst-Margetic ${ }^{1,3}$, \\ Danijel Crnković1,2,3 and Iva Ivančić Ravlić ${ }^{1,2,3}$ \\ ${ }^{1}$ Department of Psychiatry, Sestre milosrdnice University Hospital Centre, Zagreb, Croatia; \\ ${ }^{2}$ School of Dental Medicine, University of Zagreb, Zagreb, Croatia; \\ ${ }^{3}$ Catholic University of Croatia, Zagreb, Croatia; \\ ${ }^{4}$ Department of Anesthesiology, Intensive Care and Pain Therapy, Sestre milosrdnice University Hospital Centre, \\ Zagreb, Croatia
}

\begin{abstract}
SUMMARY - In 1937, Ugo Cerletti and Lucio Bini performed electroconvulsive treatment (ECT) in Rome for the first time. That was the time when different types of 'shock therapy' were performed; beside ECT, insulin therapies, cardiazol shock therapy, etc. were also performed. In 1938, Cerletti and Bini reported the results of ECT. Since then, this method has spread rapidly to a large number of countries. As early as 1940, just two years after the results of the ECT had been published, it was also introduced in Croatia, at Sestre milosrdnice Hospital, for the first time in our hospital and in the then state of Yugoslavia. Since 1960, again the first in Croatia and the state, we performed ECT in general anesthesia and continued it down to the present, with a single time brake.
\end{abstract}

Key words: Electroconvulsive therapy; General anesthesia; History; Hospital; Croatia

\section{General History of Electroconvulsive Therapy}

Electroconvulsive therapy (ECT) is one of the oldest methods of treatment in psychiatry, which was first introduced into clinical practice in Rome in 1937. Another name for such therapy was 'shock therapy'; insulin therapy and chemical convulsive therapy were also classified into this category. The concept of 'shock therapy'originated in France in the 1920s, and in 1926, the French psychiatrist Constance Pascal introduced this term into psychiatric practice ${ }^{1}$. ECT was also included in one of the four somatic therapies for the treatment of psychiatric diseases, which have been

Correspondence to: Assist. Prof. Vjekoslav Peitl, $M D, P h D$, Department of Psychiatry, Sestre milosrdnice University Hospital Centre, Vinogradska c. 29, HR-10000 Zagreb, Croatia

E-mail: vjekoslav.peitl@gmail.com

Received August 10, 2020, accepted August 30, 2020 used since the 1930s. The first such therapy was the aforementioned insulin therapy, which was introduced in clinical practice in 1933 by the Austrian psychiatrist Manfred Sakel. Based on his observations, he concluded that increased adrenaline levels were responsible for many mental health problems and began using insulin as an adrenaline antagonist. Then, in 1934, chemical convulsive therapy was introduced, initially with camphor and then with cardiazol (Metrazol). Egas Moniz began to practice prefrontal lobotomy 1935. In 1938, Ugo Cerletti and Lucio Bini in Italy started using ECT, which is the only one of the four somatic therapies used until today ${ }^{2}$. As noted above, discovery of ECT was preceded by discovery of chemical convulsive therapy. In the late 1920s, a Hungarian psychiatrist and researcher Ladislas Meduna was involved in the investigation of epilepsy histopathology, where he found on two occasions that the condition of patients 
with schizophrenia had improved after an epileptic seizure. Based on that observation, he concluded that there was a certain biological antagonism between these diseases. The results of a scientific study in which eight of 6000 patients with schizophrenia suffered from epilepsy contributed to this theory. This led to the idea of inducing epileptic attack with a chemical agent, which was yet to be discovered. Meduna identified camphor as an active substance that met the required criteria and on January 2,1934, he applied camphor by intramuscular injection in a human for the first time ${ }^{3}$. In his autobiography, Meduna described a patient who had been in catatonic stupor for four years, lay in bed like a wooden figure, did not move, refused food and had to be fed through a nasogastric tube. After administering 5 injections of camphor, for the first time in four years, the patient got out of bed on his own, started talking, even asked for breakfast himself, and became interested in his surroundings. Meduna believed that predisposition for epilepsy was a simple indicator of the patient's ability to self-recover ${ }^{4}$. Over the next two years, he applied ECT in more than 100 patients, at least half of which recovered. Over time, camphor was replaced with another agent, cardiazol (Metrazol), which he found to be able to cause epileptic attacks at high enough doses. Soon, such treatment became known as convulsive therapy ${ }^{3}$. A few years later, in 1937, a conference on pharmacological convulsive therapy was held in Switzerland, organized by psychiatrist Max Müller. The Proceedings on Convulsive Therapy was published in the American Journal of Psychiatry and, over the next three years, convulsive therapy began to be applied worldwide. However, certain serious complications of such treatment have been reported, such as unpleasant sensations and intense fear preceding loss of consciousness, general restlessness, vein thrombosis, and vertebral fractures following severe epileptic seizures induced with cardiazol. Such treatment was dangerous and costly and the performance was complicated for medical staff, which led to the search for alternative ways of causing seizures. One way was to use electricity to induce seizures. The initiators of this form of therapy were Italian Professor Ugo Cerletti and his colleague Lucio Bini, who began using electric shocks to cause epileptic attack in animals. The idea of using electroshock (ES) in humans developed when Cerletti saw the use of ES for anesthesia in pigs before slaughter. At meetings in Münsingen in 1937,
Lucio Bini described the process of inducing an epi attack by electrical stimulus in dogs using a self-designed apparatus. What both Meduna and Cerletti observed was that the cause of the epileptogenic stimulus was not important but rather the most important thing was the epileptic seizure, regardless of how it was induced. The method consisted of the initial application of a weak calibration current that passed through two electrodes positioned on the patient's head with a special support structure that measured head resistance. Based on this value, an adequate voltage level would be chosen to trigger an epi attack. The first company to be licensed to produce Bini's ES apparatus was Officine Elettrotecniche Italiane Ing. Vittorio Arcioni S.a.s. In October 1938, Lucio Bini applied for a patent that was protected in March 1939, officially becoming the inventor of ECT apparatus 5 .However, such attacks were accompanied by numerous and serious complications and his colleagues continued to search for the characteristics of electricity that would cause a less severe attack that would be safer for patients. They concluded that current of $125 \mathrm{~V}$ with a duration of one second on the bitemporal electrodes was safe. In April 1938, ECT was first applied in humans. It was a patient who was found wandering the streets of Rome, spoke in neologisms, had thought-provoking phenomena, with emotional detachment. He had been successfully treated previously with cardiazol on numerous occasions. Following the first application, the patient spoke coherently, after which the ES was applied 10 more times ${ }^{3}$. Soon the ECT was applied not only in Italy but in other parts of the world as well. Dr. Renato Almassi, Professor Cerletti's associate in Rome, brought the ECT apparatus to the USA. The first ES in America was administered by Dr. David Impastato at Columbus Hospital, New York, in January $1940^{2}$. Apart from him, Lothar Kalinowsky, a German psychiatrist who practiced psychiatry in Rome with Cerletti before emigrating to New York in 1940, is mentioned as one of the significant initiators of ECT in the USA ${ }^{1}$. At the same time, ECT began to be applied sporadically in the Scandinavian countries, most notably in Denmark and Sweden, where it entered in regular use at university departments as early as the end of 1940. In the UK, they began to apply ECT in 1938, but after 1960 it was more stigmatized than in the US ${ }^{1}$.In order to modify the use of electricity in 1942, Emerick Friedman and Paul H. Wilcox in 
Massachusetts proposed setting up a unilateral electrode to reduce cognitive impairment in patients. In addition, there were techniques where a shorter impulse current was applied and was called short stimulus therapy. Wladimir Liberson in Connecticut proposed this type of therapy that used currents that were $1 / 30$ of Cerletti's dose and thus shortened pulses, and invented a machine that could generate up to 250 such pulses per second. Later, Liberson increased the pulse amplitude with each cycle and with this mode, excellent results were reported in depressed patients ${ }^{1}$. There has long been controversy over positioning of electrodes, which method has fewer side effects and greater efficiency. It was later found that high doses in the right unilateral ECT acted as well as bilateral $\mathrm{ECT}^{6}$. The advantages of ECT over chemical convulsive therapy were the simplicity of the technique, safety of the reaction, faster and more efficient loss of consciousness (thus eliminating the unpleasant feeling of fear) and the possibility of applying muscle relaxants ${ }^{7}$. However, the goal was to find a way of eliminating convulsions while maintaining therapeutic effect. In order to reduce the strong physical exertion of the patient during convulsion, various methods were used to achieve muscle relaxation. ECT with the use of barbiturates and myorelaxants is called mitigated ECT. The pioneer of the mitigated ES was E.E. Benett who used the curare muscle relaxant for the first time in 1940 to relieve convulsions. Ten years later, succinyl compounds were introduced and are still in use today. The effect of succinyl was visible shortly after the application when fasciculation of the affected musculature occurred. Since succinyl compounds also cause respiratory musculoskeletal paralysis, which was an extremely uncomfortable feeling for a conscious patient, prior anesthesia was necessary. At that time, barbiturates, sub-convulsive doses of electrical current, and inhalation anesthesia were used for the induction of anesthesia. The mortality rate of native ES was very low, with some studies suggesting $0.05 \% 0$ to $0.2 \%$ of treated patients, but in the first phase of the introduction of mitigation, mortality increased due to a defective technique, extension of indications and significant deficiencies of the induction agents that were in use at that time. However, the mitigated ES had numerous benefits because it reduced the patient's fear and the likelihood of complications such as fractures, luxations, bites, myalgia, and also mortality was equal to that of general anesthesia ${ }^{8}$.

\section{Electroconvulsive Therapy in Croatia}

Electroconvulsive therapy has been used in Croatia since 1940, at the Sestre milosrdnice Hospital, now Sestre milosrdnice University Hospital Centre (UHC). The application of ECT at Sestre milosrdnice UHC began shortly after founding of the Department of Neurology and Psychiatry at Dr. M. Stojanović General Hospital in spring 1940. Although there "has been not a single case of fatal outcome as a direct or indirect complication of unmodified ECT since the founding of this Department, a mitigated electroshock has been introduced." ${ }^{8}$. According to this report and medical records available, it is evident that ECT has been practiced in our hospital for 80 years now, i.e. since the very foundation of the Department of Neurology and Psychiatry. During World War II, an apparatus was purchased for the Neuropsychiatric Department, which was then located in Kukoviceva Street (now, Faculty of Chemical Biotechnology is located in these premises), predecessor of the present Department of Psychiatry, Zagreb University Hospital Centre. It was also noted that during insulin shortage in today's Vrapče Psychiatric Hospital during World War II, ECT began to be applied by borrowing the apparatus from the institutions in Zagreb that had it ${ }^{9}$. Already in 1960, we introduced ECT under general anesthesia or mitigated ES, as it was then called (Fig. 1). This procedure was introduced for the first time in Croatia and in the former state. Boško Barac, then specialist in our neuropsychiatric school, wrote: "Hudolin, an ambitious and hardworking doctor, had a lot of misunderstandings with his associates. He wanted to introduce newer methods of treatment. Convinced that ES was unsurpassed in some psychiatric disorders, he was right to introduce a 'mitigated' ES under anesthesia with muscle relaxants due to possible dangerous complications. At that time, there was no 'ethics committee', so Prof. Danko Riessner (1907-1973), a pioneer of Croatian neurosurgery and Head of Surgery in Vinogradska Hospital, appointed me, along with the chief of anesthesia Dr. Neda Butigan (1929-1993), to be the first in Croatia and Yugoslavia to introduce this method as a routine. Trained in the basics of anesthesia and resuscitation and having mastered the technique of intubation, for a long time I practiced 'mitigated ES' with Hudolin's formal assistance" ${ }^{10}$. 


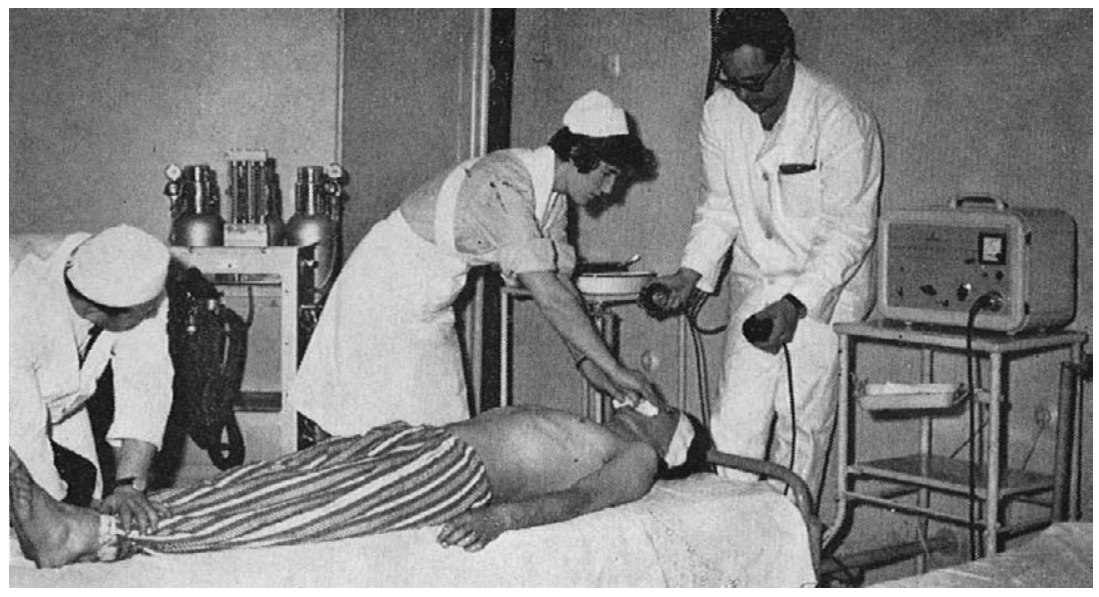

Fig. 1. Photograph from the 1960s when electroconvulsive therapy was performed under general anesthesia at Department of Psychiatry, Sestre milosrdnice University Hospital Centre. In the foreground is the Siemens Convulsator 622, used at the Department since the 1950s, while an older Siemens model was used before.

In our routine, mitigated ES was used in selected cases, most often in those that had a strict contraindication for unmodified ES. Included in the group of patients with absolute contraindication were those with osteoporosis, osteoarticular lesions and deformities, or patients with strong musculature who were at risk of developing complications and patients with more severe cardiovascular disease (cardiac valve damage, high hypertension, more severe atherosclerotic lesions, fresh cerebrovascular incidents, increased intracranial pressure, etc.). A medical team consisting of physicians educated in the basics of anesthesia and resuscitation, and a nurse who also had appropriate anesthesia training, participated in the implementation. Patients were comprehensively clinically assessed prior to ECT. During the course of therapy, vital parameters were monitored along with other data (blood pressure, pulse, onset and end of apnea, etc.). An example of anesthesia chart used back then can be seen in Figure 2. The amount and time of administration of all medical agents was also recorded on special lists. The patients were on an empty stomach, with an empty bladder. Premedication was performed with $0.5 \mathrm{mg}$ of atropine, most commonly before barbiturate administration. In this way, salivation and cough stimulation were prevented and the whole procedure was safer for the patient. After atropine, $10 \%$ barbiturate (Kemithal) was injected with clinical titration at doses of 300 to 1000 $\mathrm{mg}$. Then, a Leptosuccin (45-90 mg) muscle relaxant was administered to the same needle to achieve safer relaxation. After half a minute, facial fasciculations would usually occur and then pure oxygen would be applied via the mask with $\mathrm{CO} 2$ absorption using the Sutjeska 1958 inhalation anesthesia device. After a dozen passive breaths, electricity was applied using the Siemens Convulsor 622 and a generalized type convulsion would occur (Fig. 1). The patient was then briefly ventilated with oxygen but without $\mathrm{CO} 2 \mathrm{ab}-$ sorption to accelerate spontaneous breathing. This whole process took 12 minutes per application. In this way, from February 1960 to February 1961, a total of 30 patients were treated with a total of 120 applications. Temperature charts from the 1960s are shown in

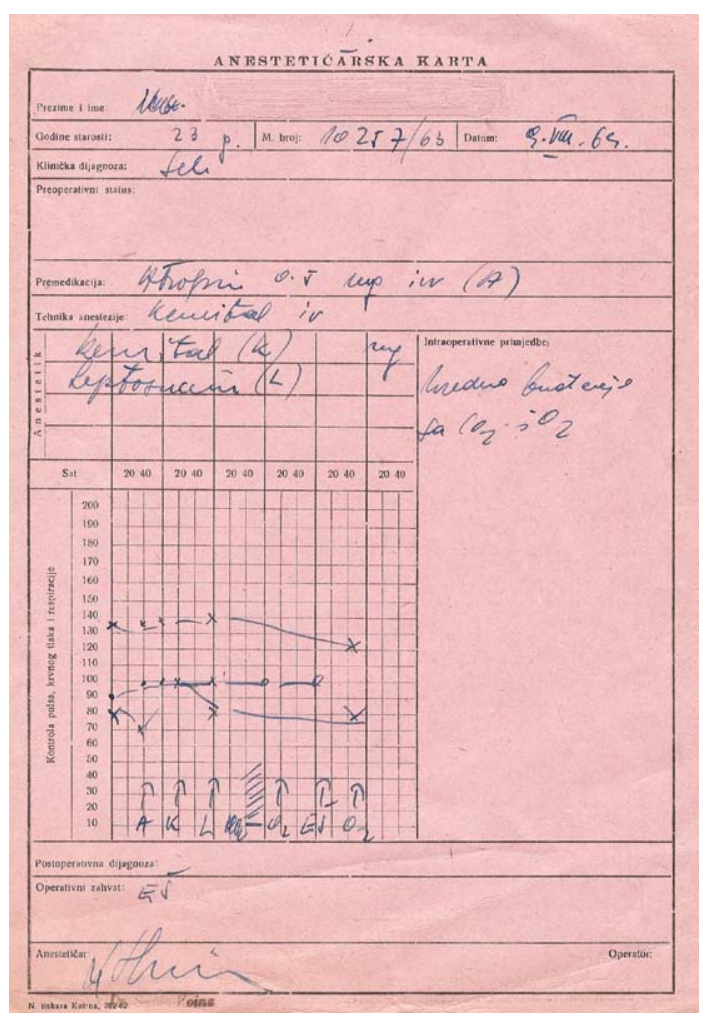

Fig. 2. Anesthesia chart from the 1960s. 


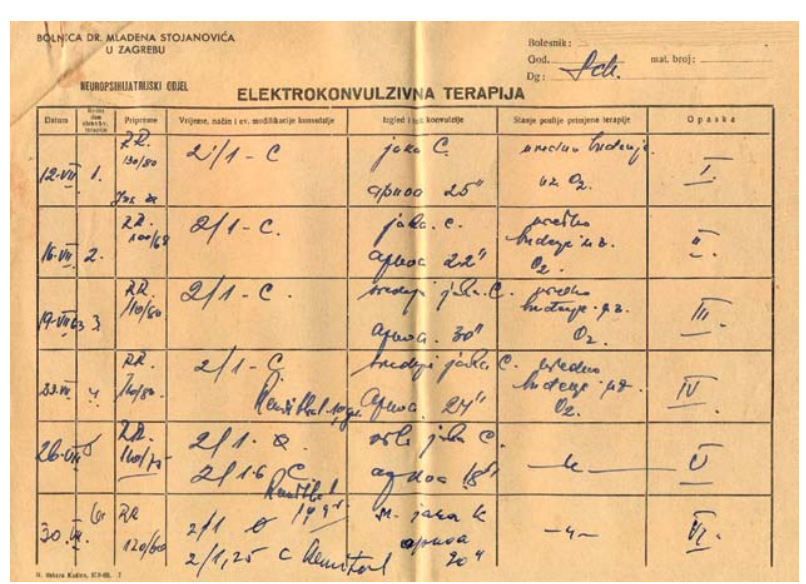

Fig. 3. Electroconvulsive therapy application chart from the 1960s.

Figures 3 and 4, reflecting the concomitant use of psychopharmacotherapy and ECT, along with the measurement of vital parameters. The risk of cardiovascular complications was the cause of mitigation in $50 \%$ of cases, the risk of osteomuscular incidents in $20 \%$ of cases, and fear of native ES in others ${ }^{8}$. From the statistics of the neuropsychiatric ward, a total of $139 \mathrm{pa}^{-}$ tients were treated from 1964 to 1968. Of the total number of patients, there were 111 men and 28 women. Their age ranged from 17 to 62 years, with the highest number of patients in the 20-30 age group. There were 127 patients with schizophrenia, most often with a clinical picture of paranoid hallucinatory psychosis, or catatonia. After 2 to 3 applications of ES, improvement in the patient's mental status was reported. During hospital stay, they would have received 5 to 10, maximum 15 to $20 \mathrm{ES}$. Of the 139 patients treated, 15 were administered mitigated ES. Complications included surgical complications (mandibular luxation in 14 patients and compressive Th4-5 fracture in one patient), prolonged apnea, dyspnea in two cases, and twilight state in one patient. At that time, there were several ways of treatment with ES. The first way was to achieve a typical grand mal convulsion. Secondly, the electric current did not reach the convulsive threshold but caused the onset of short-term loss of consciousness with spasms of the musculature, but without the appearance of tonic-clonic seizure, which was called ES balance. This method was recommended for the elderly, those in poor general condition and in the stage of fracture consolidation. In special cases, in acute schizophrenic conditions and in acute death

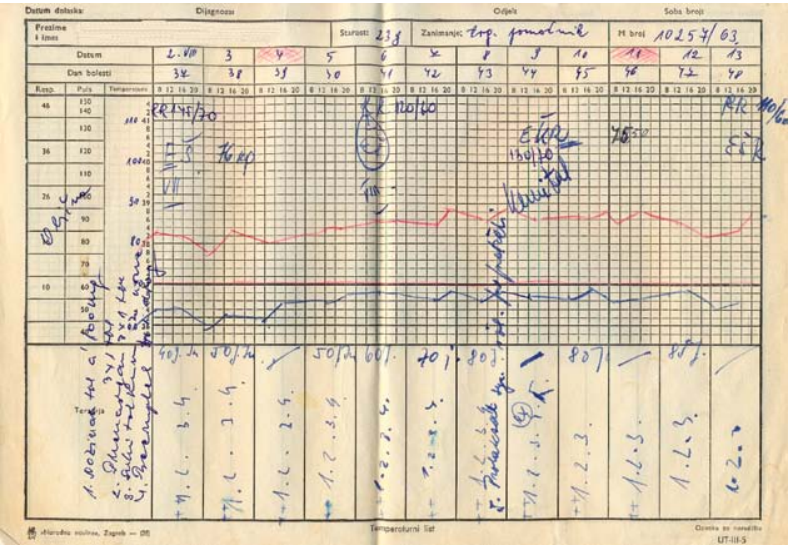

Fig. 4. Temperature sheet from the 1960s showing concomitant use of pharmacotherapy and electroconvulsive therapy.

catatonia, block treatment was used, consisting of 3-4 consecutive applications of ES daily for several days ${ }^{7}$.

\section{Antipsychiatry Movement and ECT}

The beginning of the anti-psychiatric movement goes back to the 1950s with the emergence of a division between biological and psychoanalytic psychiatrists. Biological psychiatrists resented institutionalization of patients, administration of high doses of neuroleptics, convulsive therapy with psychosurgery, whereas analytically oriented psychiatrists resented the non-scientific bases of psychoanalysis, which was considered costly and ineffective. The term 'antipsychiatry' was created in 1967 and was introduced by David Cooper, a South African psychoanalyst, many years after the movement had really begun. Other psychiatrists participated in the promotion of the antipsychiatry movement, most notably Michael Foucault in France, Ronald David Laing in the UK, and Thomas Szasz in the US. Alleged psychiatric abuse of patients by ECT was also popularized in Kesey's novel One Flew over the Cuckoo's Nest from 1962 and later through the film adaptation of the said nove ${ }^{11}$. The antipsychiatry movement and the influence of the media thus added to the already existing stigma associated with ECT. The development of psychopharmacology in the 1960s also contributed to the antagonism, marginalization and stigmatization of ECT, given that this treatment seemed even more barbaric compared to the administration of drugs ${ }^{1}$. Public and professional per- 
ceptions of ECT as an invasive brain-damaging method caused the greatest controversy. Such beliefs fueled primitive fears of 'soul damage' that represents each person's uniqueness. Due to all of the above, ECT was neglected by educators and a large number of psychiatrists who completed their education between 1960 and 1980, resulting in their deficiency in knowledge of this field ${ }^{12}$. However, over time, a new problem came to light, which was therapy-resistant depression. Kurt Witton, a psychiatrist who studied in Bologna and later emigrated to the US, in 1962 noted a significant improvement in neuroleptic-resistant patients after ECT, which again put the focus on the application and effectiveness of ECT. The American Psychiatric Association (APA) contributed to the return of ECT to clinical practice, setting up a working group for scientific evaluation of the effectiveness of ECT in 1975. The report of the Working Group in 1978 was positive, and it was found that ECT had an essential role in the treatment of major depressive disorder, resistant mania and therapy resistant schizophrenia. In addition, guidelines for informed consent to ECT were been agreed, which led to the less authoritative approach to patients. In 1981, the Royal College of Psychiatrists in the UK published similar guidelines for the application of ECT. Due to the repeated public pressure to limit ECT, in 1985 the National Institute of Mental Health organized a consensus conference. A group of participants concluded that ECT was an effective treatment for a limited number of mental illnesses and that its use was safe when applied according to guidelines. They also recommended better monitoring of the ECT implementation, the creation of additional national standards and better education, which prompted the APA to set up a second working group in 1990, which produced a more comprehensive report detailing indications, risks, informed consent and technical procedures for the application of modern and modified ECT, thus declaring that ECT plays a crucial role in psychiatric treatment ${ }^{1,12}$. Over time, the guidelines have become part of the continuing medical education creating better collaboration between psychiatrists and anesthesiologists, which has contributed to the creation of medical teams capable of treating patients with severe somatic conditions, for whom ECT has been a viable option. In addition to the US, attacks from the public and various organizations were also present in other countries around the world. In the UK and Ireland, reports were also published in 1981 and 1982 concerning the use of ECT, and it was restricted to private institutions and university departments. In some parts of India and China, unmodified ECT is still applied as it was 80 years ago ${ }^{12}$. More than 80 years have elapsed since the discovery and introduction of ECT into psychiatric practice, during which the ECT has experienced several ups and downs, from stigmatization and marginalization to the recognition of the effectiveness and safety of the therapy itself. Nowadays, ECT is recognized as a superior method in the treatment of therapy resistant depression, suicidality, catatonia or mania, despite the fact that the exact neurochemical profile of ECT has not yet been discovered.

\section{Current Situation in Croatia}

In Croatia, the use of ECT is now regulated by the Act on the Protection of Persons with Mental Disorders ${ }^{13}$. The Act states that ECT may be applied to a person with mental disability if the person with mental disability has provided a written consent, if all other treatments have previously been exhausted, if the use of ECT is reasonably expected to be of real and direct benefit for the health of that person, and without adverse side effects, of which opinion is given by the department physician, and ultimately if the ethics committee of the psychiatric institution or the ethics committee of the health institution has given positive opinion on the ethical acceptability of the use of $\mathrm{ECT}^{13}$. In Croatia, ECT is being applied today at Sestre milosrdnice University Hospital Centre (SMUHC) and Zagreb University Hospital Centre. At SMUHC Department of Psychiatry, ECT is applied after undergoing diagnostic procedures according to the protocol for ECT, which includes blood panel (complete blood count, basic metabolic panel, thyroid hormone level), electrocardiogram, chest $\mathrm{x}$-ray, brain computed tomography, and examination by ophthalmologist and anesthesiologist, then signing the informed consent and approval granted by the SMUHC Ethics Committee. The ECT is administered bilaterally (in some cases unilaterally) under general anesthesia usually on 6 to 12 (in rare cases more than 12) occasions using a Thymatron System IV apparatus. Before general anesthesia, atropine is administered to decrease salivary 
and bronchial secretion, and in some cases during anesthesia to keep the heart beat normal. Induction and maintenance of anesthesia is achieved with the intravenous agent propofol combined with nondepolarizing muscle relaxant succinylcholine ${ }^{14}$. After induction, standard routine monitoring is conducted. Patient is ventilated with $100 \%$ oxygen at a rate of $15-20$ breaths/ min, beginning approximately $1 \mathrm{~min}$ before the induction and continued until resumption of spontaneous breathing. ECT is administered by a psychiatrist. Ultra short pulse stimuli are used to trigger epileptic seizure. The power required to reach the neuromodulatory threshold is titrated to the achievement of the tonicclonic seizure recorded on the electroencephalogram. During the seizure, electromyogram and electroencephalogram are monitored. Vital signs, agents for anesthesia, stimulus parameters, and duration of the spike wave complex are also noted on special charts. Many of our patients notice improvement after 6 treatments and if needed we recommend maintenance therapy once a month after discharge from the hospital. This is the process of ECT treatment used at our Department of Psychiatry with which we have good results and which has proved effective when used according to the guidelines.

\section{References}

1. Swartz CM. Electroconvulsive and neuromodulation therapies. NY: Cambridge University Press; 2009.

2. Lebensohn ZM. The history of electroconvulsive therapy in the United States and its place in American psychiatry: a personal memoir. Compr Psychiatry. 1999;40:173-81. doi: 10.1016/ s0010-440x(99)90000-7
3. Gazdag G, Ungvari SG. Electroconvulsive therapy: 80 years old and still going strong. World J Psychiatry. 2019;9:1-6. doi: 10.5498/wjp.v9.i1.1

4. Fink M. Meduna and the origins of convulsive therapy. Am J Psychiatry. 1984;141(9):1034-41. doi: 10.1176/ajp.141.9.1034

5. Rzesnitzek L, Lang S. A material history of electroshock therapy. Electroshock technology in Europe until 1945. NTM. 2016;24:251-77. doi: 10.1007/s00048-016-0152-5

6. Abrams R, Swartz CM, Vedak C. Antidepressant effects of high-dose right unilateral eElectroconvulsive therapy. Arch Gen Psychiatry. 1991;48:746-8. doi: 10.1001/archpsyc.1991. 01810320070010

7. Solter-Lajko V. Electroshock in modern psychiatry. Psihijat Njega. 1970;5:141-6.

8. Barac B, Hudolin V1. Our experience of mitigation ES with barbiturates and relaxation agents. Annals of the Hospital "Dr M. Stojanovic". 1962;1:374-84.

9. Turčin R, Lipovac M, Matijaca B. Psychiatric Hospital Vrapče 1879-1979. Zagreb: Psihijatrijska bolnica Vrapče; 1979.

10. Barac B. Pola stoljeća života s hrvatskom neurologijom. Lijec Novine. 2015;137: 67-72. (in Croatian)

11. Rissmiller DJ, Rissmiller JH. Open forum: Evolution of the antipsychiatry movement into mental health consumerism. [Psychiatry online Web site]. June 1,2006. Available at: https:// ps.psychiatryonline.org/doi/full/10.1176/ps.2006.57.6.863 Accessed April 4, 2020.

12. Fink M. Impact of the antipsychiatry movement on the revival of electroconvulsive therapy in the United Sates. Psychiatr Clin North Am. 1991;14:793-801. doi: 10.1016/S0193-953X(18) 30270-3

13. Act on the Protection of Persons with Mental Disorders, IV, Art. 18. Official Gazette No. 76/14. (in Croatian)

14. Kadiyala PK, Kadiyala LD. Anaesthesia for electroconvulsive therapy: an overview with an update on its role in potentiating electroconvulsive therapy. Indian J Anaesth. 2017;61:373-80. doi: 10.4103/ija.IJA_132_17

Sažetak OSAMDESET GODINA ELEKTROKONVULZIVNE TERAPIJE U HRVATSKOJ
I U KLINIČKOM BOLNIČKOM CENTRU SESTRE MILOSRDNICE

\author{
D. Karlovic, V.A. Badžim, M. Vučic, H. Krolo Videka, A. Horvat, V. Peitl, A. Silic, B. Vidrih, \\ B. Aukst-Margetić, D. Crnković i I. Ivančić Ravlić
}

Ugo Cerletti i Lucio Bini prvi put su izveli elektrokonvulzivnu terapiju (EKT) 1937. godine u Rimu. To je bilo doba kada su se provodile različite vrste "šok terapija”; uz EKT bile su to još inzulinske terapije, kardiazolski šokovi itd. O rezultatima EKT Cerletti i Bini izvijestili su 1938. godine i od tada se ta metoda vrlo brzo proširila u velik broj zemalja. Već 1940., samo dvije godine nakon objave rezultata o EKT, uvodi se i u Hrvatskoj u Bolnici Sestara milosrdnica, prvi puta u nas i u ondašnjoj državi Kraljevini Jugoslaviji. Od 1960. godine, opet prvi u Hrvatskoj i ondašnjoj državi, u našoj bolnici radimo EKT u općoj anesteziji sve do današnjih dana samo s jednim prekidom.

Ključne riječi: Elektrokonvulzivna terapija; Opća anestezija; Povijest; Bolnica; Hrvatska 